\title{
Nigeria-Turkey Relations: An Overview
}

\author{
Hamman Abubakar Bashir \\ Kadir Has University, Istanbul, Turkey
}

Doi:10.19044/esj.2018.v14n35p247 URL:http://dx.doi.org/10.19044/esj.2018.v14n35p247

\begin{abstract}
Interests of sovereign states transcend across friendships of individuals, commonalities in cultures and beliefs and most importantly, economic gains (the genesis of constant competition for expansion and hegemony in today's international system). Over the years, Turkey's foreign policy has impacted on many African nations in many ways. It is either trying to compete with other powerful nations such as China and India or participating in Humanitarian activities in places such as Somalia, Sudan and Niger. Moreso there seems to be a need to analyse the interest of Turkey in one of Africa's most powerful countries, and Turkey's close ally in Africa, Nigeria. It has been a century of codial relationship between the two countries, before the major diplomatic down-turn that occured after the failed coup attempt in Turkey. The paper also tries to analyse the AKP foreign policy toward Nigeria. Therefore, this paper analyzes the relationship and interests of Turkey in Nigeria. The paper will also analyse why the choice of Nigeria and not other countries on the continent. It will also critically discuss the strategies and failures of Turkish foriegn policy in Nigeria. The study uses the qualitative research method by critically analysing existing relevant studies published in journals, books, conference proceeds, media reports, parliamentary debates and so on. Propositions in this study are based on foreign policy perspective as the theoretical framwork. Findings show that the relationship between the two countries dates back to the Ottoman era. The paper tries to explore the origin and development of the relationship over the years. As the paper reflects from a foriegn policy perspective, it will analyse factors that form substance of the foreign policy analysis.
\end{abstract}

Keywords: FPA, OIC, MFA, AKP, NEO-OTTOMANISM

\section{Introduction}

Turkey and Nigeria are located on two different continents of the world. Despite the commonality of religion (Islam) that Turkey shares with $60 \%$ of Nigeria's population, it is hard to project the outcome of such a complicated relationship that has existed for centuries, long before the 
Republics of Nigeria and Turkey were born. To understand Turkey-Nigeria relations, the paper takes a foreign policy analysis perspective. Considering the relationship dates to centuries ago, the paper first analyses the historical relations. Turkey is a country with a growing appetite for expansion into Africa and Middle East (based on foreign trade expansion and joint ventures).Turkey opened its embassy in Nigeria just four month into Nigeria's independence in October 1960. The embassy was etablished on 16 February 1960. Nigeria is the most populace black nation in the world, and has enjoyed Turkish friendship since the Ottoman empire era. With the population of 180 million people and a growing affluent middle class, Nigeria has had cause to make many friends on the international stage, especially, countries with interest in export of their products. During the Ottoman era, Sultan Abdulhamit II was said to have had a cordial relationship with the Amir of Kanem Bornu Empire. Kanem Bornu empire is situated in today's north eastern Nigeria. During the Cold War, the limitations put by the crisis hindered the possibility of establishing trans-continental foreign policy objectives. However, after the end of the Cold War and the collapse of the Communist Bloc, emerged the possibilities and oppotunities for state relations, although with challenges. Turkey over the years has concentrated more on relations with the European Union, Balkans, Asia and Middle East in comparism to Africa. However, on the international stage, Turkey and Nigeria have been comembers of the organisation of Islamic counries (OIC). This gives a basis for friendship and and pursuit of a common interest.

\section{Research Aim and Questions}

The questions this paper asks are: (1) Why does Turkey need relations with, specifically, Nigeria? (2) What is the gain for Nigeria and Turkey in the relations? (3) Has Nigeria-Turkey relations yielded any positive outcome? The paper is an attempt to analyse Turkey-Nigeria relations and the changes that have occured. It also aims to analyse Turkish foreign policy toward Nigeria, the historical ties between the two countries and policy failure and success. The next section covers background study of the relations and the subsequent sections review response to the research questions.

\section{Conceptual Clarification}

Foreign policies are strategies governments use in dealing with each other. It is about whatever Governments choose to do or not to do with other nations (Dye, 2012 p.12). Such policies may include trade agreements, sanctions, military cooperation, diplomatic accords etc. While these policies are tailored towards serving the interests of nations involved, they may sometimes have undesirable impact that may lead to other bigger problems than it sought to address, ruin government agenda time, and even lead to the 
let-down of governments (McConnell, 2016). These undesirable impacts have been described as policy disasters (Dunleavy, 1995), policy blunders (King and Crewe, 2013) and now policy failure (McConnell, 2016). Understanding policy failure helps to completely understand the impact of foreign policy especially as the success of foreign policy-which is often seen as achievement of set goals - is much projected by national governments (Gupta, 2010). Therefore impact of foreign policy in this paper is considered from the success or failure of policy. What is known as foreign policy success lies in the positive of what has been used to assess policy failure.

\section{Theoretical Framework}

In 2002, the AKP (Justice and Development Party) came to power in Turkey with Recap Tayyip Erdogan as prime minister, and Ahmet Davutoglu as the minister in charge of foreign affairs. The AKP rode on the Foreign policy of Professor Ahmet Davutoğlu. Davutoğlu is the author of Turkish strategy (Turkish Grand Strategy) which according to Novi Standard (2010) constitutes 'the ideological depth constant of the Turkish foreign policy'. The neo-ottoman notion that sprang from the era of ottoman empire is still very much in the heart of Turkish foreign policy. Although, on many cases Turkish diplomats deny neo-ottomanism as the foreign policy direction and the country's attachment to the past glory of the ottoman empire. However, according to Davutoglu, Turkey must sustain good relations with Africa, have a say in Asia and remain a power-house in the Middle East. He posits that Turkey cannot be compared with national states formed in the 20th century; its standing in the international system should only be compared with former empires like France, Germany, British empire, China, Russia and Japan (Pajaziti, 2012).

Davutoglu in his book 'Strategic Depth' published in 2001 elaborates that Turkey should not be satisfied with a regional power role in the Middle East, Africa and the Balkans. He describes Turkey as a state with 'Strategic Depth' due to its geographical position and ottoman history; hence Turkey's appetite for expansion and massive investment in Africa's economic pot, Nigeria (Grigoriadis, 2010).

Grigoriadis (2010) posits that:

"Turkey's growing interest in hitherto neglected parts of the globe is another feature of the implementation of Davutoğlu's doctrine. Sub-saharan Africa and Latin America attracted unprecedented attention by Turkish diplomatic authorities. A series of Turkey-Africa summits were organised in Turkey with the participation of numerous African leaders. In a speech Davutoğlu delivered in December 2009, he stated that seven new embassies were opened in 2009, while twenty-six would open in 2010 most of which in 
sub-Saharan Africa and Latin America. He also announced his intention to ask for a sharp rise of the budget Working Paper 8/2010 9 and the personnel of the Turkish Foreign Ministry, so it could stand up to the new role he envisioned for Turkey"

Geo-politics has played a significant role in creating a soft landing platform for Turkey in Africa. Turkey's role in Somalia has brought goodwill for Turkey and Turks in Africa. This singular act has been instrumental to Turkey's tremendous gains in Africa. Turkey's earnings from Africa have grown tenfold in the last two decade (Aybar and Gital, 2018).

\section{Foreign Policy Analysis}

Foreign policy analysis (FPA) is the study of the conduct and practice of relations between different states in international relations (Uchehara, 2008). However, the decisions of many leaders have led their countries to prosperity or have plunged them in a long life crisis. Some leaders have ruined themselves through foreign policies that are not well sort; Iraq's Saddam Hussein's invasion of Kuwait is a typical example (Breuning, 2016). Whether it is diplomatic relations, intelligence sharing, wars, trade negotiations and cultural exchanges between the peoples of both nations, foreign policy analysis touches on those areas and more. By virtue of this approach, foreign policy analysis is necessarily concerned with the boundaries between the external environment outside of the nation state and the internal or domestic environment, with its variety of sub-national sources of influence (Grigoriadis, 2010). Foreign policy analysis, as foreign policy analysis is often referred to, developed as a separate area of enquiry within the discipline of international relations, both because of its initially exclusive focus on the actual conduct of interstate relations and due to its normative impulse (Uchehara, 2008).

\section{Policy Failure and Success}

Foreign policy impact has been gauged on the scale of achievement or not of what was intended by the policy strategy. This approach has been used extensively by academic as well as by most governments in assessing the success or failure of their foreign policy (Gupta, 2010). For example, Pressman (2009) assessed the U.S Foreign Policy in Iraq under President George W Bush using this approach and concluded that since the U.S did not achieve its goal to put an end to terrorism and entrench democracy in the Middle Eastern nation, then the U.S Foreign Policy in Iraq failed. The success of foreign policy therefore would be the achievement of government's set goals in another nation.

Another definition of foreign policy failure is considered as when the interest of the target group is not served. Impact of foreign aids is often assessed based on this criterion (Booth, 2012). In that light, foreign policy 
success is serving the interest of the target group. However, when the benefits of serving the target group or national interest do not outweigh the cost, it is often regarded as policy failure (Gupta, 2010) or when the benefit does not meet more, ethical and legal standards. Also when the impact of the foreign policy is such that it does not improve on what went before and the condition in one nation is worse off before the policy as a result of what the policy did or failed to do, is considered a foreign policy failure (McDonough, 1998).

However, it is important to clarify that every foreign policy can achieve a certain level of success and that failure is not all or nothing (McConnell, 2016). Also, foreign policy goals are flexible and can experience contradictions where by a policy may succeed in achieving one goal and fail in another (Bardach, 2011). Nevertheless, McConnell (2016) asserts that:

"A policy fails, even if it is successful in some minimal respects, if it does not fundamentally achieve the goals that proponents set out to achieve, and opposition is great and/or support is virtually non-existent."

The conceptual framework of this study is hinged on this definition in seeking to assess the impact of Turkish Foriegn policy on Nigeria.

\section{Conceptual Framework}

McConnell (2016) delineated foreign policy failure along three lines: policy-making process failure, decision failure, and political failure. Against this framework the impact of the Turkish foreign policy on the case study nation is assessed.

\section{Policy-making process failure}

A nation's foreign policy can be said to have failed in the process if it is unable to achieve legitimacy in the form of legislative approval, if it is unable to sustain the authenticity of its initial goals as in the case of a failed attempted to get the United Nations approval for an economic sanction against another; or if it fails to build the needed coalition and support for the process (McConnell, 2016). Achieving all these implies foreign policy success.

\section{Decision failure}

Foreign policy decision or implementation failure occurs when the government is unable to carry out its policy programme in line with its set objectives or achieve desired outcomes, benefit interest group, or satisfy all moral, ethical and legal obligations in the process as well as attracting support for the decision (McConnell, 2016). Achieving all these indicates foreign policy success. 


\section{Political Failure}

This is about foreign policy enhancing electoral prospects, easing the business of governance, promotion of government's desired path and providing political benefit for government (McConnell, 2016). In the event that foreign policy is unable to achieve these, it is considered a failure.

\section{What Turkey does differently}

Turkish investors in Nigeria do not bring into Nigeria an 'all Turkish team' to form workforce in their businesses. Instead, they create employment for the local population. The value added on the communities where Turkish investments are located does not only come from earnings of local workers, but also transfer of knowledge (Aybar and Gital, 2018). For example, generally, the workforce of Chinese businesses in Nigeria is constituted by an overwhelming majority of Chinese nationals. Unlike Turkish corporations, Chinese corporations move into Nigeria with a full workforce (which totally eliminates the notion of job creation for existing unemployed population) and transfer of knowledge does not occur. Furthermore, [if] Nigerians are recruited, domestic rules and regulations are mostly flouted, leading to poor safety generally (Edwards, 2015).

\section{Formal relations between Turkey and Nigeria}

In years past, the idea of trade with the African countries was impossible in Turkish society but today a number of Turkish businessmen invest in Nigeria with good economic earnings for Turkey and indeed Nigeria. According to the Republic of Turkey's Ministry of Foreign Affairs (MFA) (2017), Turkey-Nigeria relations date back to the emergence of Nigeria as an independent nation in 1960. Two years after Nigeria's independence, Turkey opened an Embassy in Lagos, the then capital of Nigeria, specifically in August 1962. However, when Nigeria's capital city was changed to the more central state of Abuja in 1991, the Turkish Embassy moved to Abuja in 2001. Nigeria also has an Embassy in Ankara, the capital of the Republic of Turkey. Towards the end of the 1980s, commercial contacts between private business firms in Turkey and Nigeria were established. Turkey-Nigeria relations are part of a broader "Opening up to Africa" plan by the Turkish government in early 1998 as a move towards globalisation (Turkish Press Review, 2005). Turkish foreign policy for opening up to African countries, Nigeria in particular may, however, be viable if her policy would be beneficial for Turkish and Nigerian citizens. Therefore, on a general note, Turkey-Nigeria relations and state interests are both economic and political since in the present setting of international affairs the economic interest of a country cannot be pursued in isolation from its political interest or vice versa. As such, economic and political interests are complementary to one another because economic 
power affects political power. Similarly, the economic influence of a country in another country impinges on its political influence therein (Genc and Tekin, 2016).

Over the years, Turkey and Nigeria have maintained good political relations. Both Turkey and Nigeria are considered to have the political will to further improve bilateral relations in strategic fields. The reason is because both countries are members of the Organization of Islamic Cooperation (OIC) and the Developing Eight (D-8). Nigeria and Turkey maintain close cooperation in international organizations (Murinson, 2006). Commercial and economic relations between the two countries have also been improving rapidly. The bilateral trade volume has increased more than threefold since 2004, reaching 1.144,9 million USD in 2015, including Turkey's import of oil and LNG. Nigeria is the largest trade partner of Turkey in Sub-Saharan Africa as of 2014. There are many Turkish companies in Nigeria, operating mainly in the construction, manufacturing and energy sectors (MFA, 2017).

Furthermore, there have been high level state visits between both countries that have helped strengthen the relations between both nations. As a result of high-level mutual visits such as on the occasion of the First TurkeyAfrica Cooperation Summit which was held on 18-21 August 2008 in Istanbul, then-Foreign Minister of Nigeria, H.E. Ojo Maduekwe, paid a visit to Turkey and was received by the President of Turkey, H.E. Mr. Abdullah Gül. Also, the visit of former Turkish President Abdullah Gül, to Nigeria in July 2010; that of former Turkish Minister of State and Deputy Prime Minister Cemil Çiçek to Nigeria in November 2010; that of former Minister of State of Turkey Zafer Çağlayan to Nigeria in December 2010; and the visit of former Nigerian President Goodluck Jonathan to Turkey in February 2011 and that of former Nigerian Foreign Minister Aminu Bashir Wali to Turkey in December 2015 new cooperation opportunities have been grasped in every field and the legal basis for bilateral relations between the two countries has been largely completed with the signing of agreements in political, military, economic, commercial, cultural and educational fields (MFA, 2017). Following the Turkish President Recep Tayyip Erdoğan's official visit to Nigeria in March 2016, which saw Turkish Foreign Minister, Minister of Energy and Natural Resources, Minister of Economy, Minister of Environment and Urban Planning and Minister of Defence attend inter-delegations meetings, the Turkey-Nigeria Business Forum was organized. Subsequently, Turkey and Nigeria signed a memorandum of understanding (MoU) on trade and economic partnership agreement. According to Nigeria's Minister of Industry, Trade and Investment, Okechukwu Enelamah, the agreement is intended to raise the current trade volume of both countries, which currently stands at \$2.3 billion, through investments drive. Indicating how important the bilateral agreement is to Nigeria, Mr Enelamah was quoted as saying: "the relationship 
between Turkey and Nigeria is an opportunity we won't waste. Our trade volume currently stands at $\$ 2.3$ billion. We have already advanced our discussions with them, at the diplomatic level. Currently, government is facilitating discussion with up to 150 Turkish Business men and key representatives of the private sector in Nigeria to explore more areas of investments," (TheWill, 2016).

Additionally, the Turkey-Nigeria relations have also witnessed movement of people between both countries parallel with developments in trade, and there has been a consistent rise in arrivals of Nigerian nationals to Turkey since 2000. 4,238 Nigerian arrivals were recorded in 2000, rising steadily to 22,869 in 2013 (TurkStat 2013b). The difference between arrivals and departures also reveals that as a trend, more Nigerians are coming, and more Nigerians are staying in Turkey (authors own calculations from (TurkStat, 2013a, 2013b). Departures of Nigerians from Turkey have remained around 1,000 below arrivals since 2009 (down from 2,783 in 2000 but up from 131 in 2006 after a period of negative fluctuation), suggesting that at least some of those arriving from Nigeria are staying to do business, gain an education, or apply for asylum even with high visa fees. The numbers, however, are likely to be low due to the macro-institutional framework and meso-level constraints (explained in more detail below). In 2010, for example, 200 Nigerian citizens were registered in Turkey (out of 25,899 total registered from all African countries) (Republic of Turkey, 2010)

\section{Success and failure of foreign policy}

The Turkish foreign policy has been keenly followed by a large number of people over the years. Academics have tried to coin the changes and conceptualization that has brought about the new front of Turkish Foreign Policy (Kanat, 2014). In Nigeria, the Turkish policy has not had a difficult time to penatrate the market and especially, the military industry. The continued relations between Turkey and Nigeria suggest firstly, a mutually beneficial relationship that underscores a foreign policy success. The various bilateral relations both countries have had point to policy-making process, decision and political successes have been recorded. Further, the expansion of trade between both nations also indicates that the outcome of economic parleys by both nations have continued to meet the expected outcomes.

In addition, the relations between both nations have also recorded success in the war against terrorism. Since the inception of Boko Haram insurgency, Nigeria has made Turkey a strategic partner in the fight against Boko Haram. Nigeria purchased the T-129 attack helicopters to help fight the war against terrorism (NewsRescue, 2015). Nigeria is a long time buyer of Turkish weapons. Nigeria has bought weapons that have helped fight internal conflicts and rebellion uprisings. Otokar's Cobra armoured personnel carriers 
is in the history of one of the many important weapons purchased from Turkey by Nigeria. The strategic anti-terrorism partnership has brought Turkey closer to Nigeria. This is considered to be one of various factors that have determined the current state of the Turkey-Nigeria relations. Turkey has also penetrated the market and service economy over the years. It's competing partners are China, India and Norway. The structure of the federal system has made it easier for Turkey to be ahead of its competitors. This is because Turkey is portrayed as a muslim country. The 36 states in Nigeria independently sign MOU's, deals and partnerships. There are over 18 muslim dominated states in Nigeria. These states find it safer to transact with Turkey being a muslim country. However this is an unofficial formular, because Nigeria is a secular country that consists of both muslims, christians and traditional worshipers. Given the similarities in history of the two countries, it makes it even more doable for Turkey to take over from the chinese. However, Turkey has not been able to sustain theTurkey-Nigeria relations as much as its other competitors have been able to. Nigeria has not had any muslim country as close partners over the years. Therefore, this has given Turkey an upper hand over other countries.

However, a major downside or policy failure between Turkey and Nigeria emerged at the instance of the attempted coup de tat in Turkey. The embattled Turkish Government had requested Nigeria to derecognise Turkish educational institutions built by the Gulen movement. Just like many African countries, Nigeria has had investments of Gulen movement for many years. These investments have added value to the economy, and have created jobs. This, therefore, is important to Nigeria and its citizens. However, at the pick of the coup event, Turkey pressured Nigeria to close the Gulen schools and other investments or erase the name of 'Turkey' from all things connected to the movement. Since then, the romance between the two countriesgot to its lowest ebb. At some point it became very difficult for two to reconcile their differences. Turkey deported a number of Nigerians that were in touch with the movement. This resulted into a diplomatic clash. Nigeria's authority percieved the action of Turkey as a bridge of trust and a retaliation of what transpired in the process of handling the Gulen movement investments in Nigeria. Turkey has for many years, prior to coup de'tat had a clean sheet of relationship with black Africa. This however, could be linked to the region's relationship with the Ottoman empire. Ottoman empire is still perceived as the center for many Sub-Saharan Africans. The declaration of Turkey as a secular muslim country by the USA has shaped the image of Turkey in Africa and beyond. This has made Turkey a model for Nigeria and its likes. 


\section{Conclusion}

This paper has reviewed the relations between Turkey and Nigeria along foreign policy lines. It was found that both nations have had smooth relations over the years culminating in foreign policy successes. Both nations have had informal and formal interrelations that have helped to bolster the objectives of the relations in the first instance. However, the review found that the Turkey-Nigeria relations like most foreign policies have not been entirely devoid of policy failures. That is, being unable to receive approval in the policy-making, decision and political process. This was evident in the Turkish government's failed attempt to clamp down on its perceived enemy, the Gulen movement, with investments in Nigeria. Not only did the move not get legislative backing, its implementation would deny Nigeria and her citizens the benefits of those investments which the Turkish government sought to put an end to. Therefore, Turkey-Nigeria relations as with any other are based primarily on mutual benefits to both actors. However, it is recommended that foreign policies are insulated from political vendetta and clamp down actions by participating governments in other to avoid total breakdown of bilateral relations. It is also recommended that Turkish ventures in Nigeria participate more in corporate responsibility projects.

\section{References:}

1. Breuning, M. (2016). Foreign policy analysis. 1st ed. New York, N.Y.: Palgrave Macmillan, p.2.

2. Edwards, L. and Jenkins, R. (2015). The Impact of Chinese Import Penetration on the South African Manufacturing Sector. The Journal of Development Studies, [online] 51(4), pp.447-463. Available at:

3. Genc, S., \& Tekin, O. (2016). Turkey's Increased Engagement in Africa: The Potential, Limits and Future Perspective of Relations. European Journal of Economic and Political Studies, 7(1), 87-115.

4. Grigoriadis, 1. (2010). The Davutoğlu Doctrine and Turkish Foreign Policy. [online] Eliamep.gr. Available at: https://www.eliamep.gr/wpcontent/uploads/2010/05/\%CE\%9A\%CE\%95\%CE\%99\%CE\%9C\%C $\mathrm{E} \% 95 \% \mathrm{CE} \% 9 \mathrm{D} \% \mathrm{CE} \% 9 \mathrm{~F}-$ $\% \mathrm{CE} \% 95 \% \mathrm{CE} \% \mathrm{~A} 1 \% \mathrm{CE} \% 93 \% \mathrm{CE} \% 91 \% \mathrm{CE} \% \mathrm{~A} 3 \% \mathrm{CE} \% 99 \% \mathrm{CE} \% 9$ 1\%CE\%A3-8_2010_IoGrigoriadis1-1.pdf [Accessed 1 Oct. 2018].

5. PAJAZITI, A. (2012). Davutoğlu: Thinking Depth and Global Political Activism as New Grand Strategy. CONTEMPORARY issues, vol 5, no 1(5), pp.2-6.

6. Turkey's strengthening partnership with Ghana. (2018). [video] Directed by S. Aybar and A. Gital. TRT WORLD: STRAIT TALK.

7. Murinson, A. (2006). The strategic depth doctrine of Turkish foreign policy. Middle Eastern Studies, 42(6), 945-964. 
8. NewsRescue.com (2015). Buhari Orders T129 Attack Copters, Expected In 3 Months. NewsRescue.com. Retrieved 16 January 2017, from http://newsrescue.com/boko-haram-buhari-orders-t129-attackcopters-expected-in-3-months-unconfirmed/

9. Republic of Turkey Ministry of Foreign Affairs (MFA). (2011). Republic of Turkey Ministry of Foreign Affairs. Retrieved 16 January 2017, from http://www.mfa.gov.tr/relations-between-turkey-andnigeria.en.mfa

10. Republic of Turkey, M. o. L. a. S. S. a. M. o. F. A. (2010) 'Yurtdisindaki Vatandaslarimizla Ilgili Sayisal Bilgiler', Ministry of Labor and Social Security and Ministry of Foreign Affairs, 31 December, http://www.csgb.gov.tr/csgbPortal/diyih.portal?page=yv\&id=1

11. TheWill. (2016). Nigeria, Turkey Sign Economic Cooperation Agreement. Thewillnigeria.com. Retrieved 16 January 2017, from http://thewillnigeria.com/news/nigeria-turkey-sign-economiccooperation-agreement/

12. TurkStat (2013a) 'Çıkış Yapan Yabancı ve Vatandaşlar [Departing Foreigners and Citizens]', retrieved 19 January 2015 from www.turkstat.gov.tr/PreIstatistikTablo.do?istab_id=320

13. TurkStat (2013b). Giriş Yapan Yabancı ve Vatandaşlar [Arriving Foreigners and Citizens]. Retrieved 19.01.2015, from www.turkstat.gov.tr/PreIstatistikTablo.do?istab_id=320

14. Turkish Press Review, 05-11-24. (2005). Hri.org. Retrieved 16 January 2017, from http://www.hri.org/news/turkey/trkpr/2005/05-1124.trkpr.html

15. Uchehara, K. E. (2008). Continuity and change in Turkish foreign policy toward Africa. Gazi Academic View, 2(3). 